\title{
A tudós iskolaépítő. In memoriam Buday-Sántha Attila (1941-2014)
}

\author{
A founding father. In memoriam Attila Buday-Sántha \\ (1941-2014)
}

\author{
HORVÁTH GYULA
}

\begin{abstract}
HORVÁTH Gyula: tudományos tanácsadó, MTA Közgazdaság- és Regionális Tudományi Kutatóközpont, Regionális Kutatások Intézete, Pécs; horvath@rkk.hu
\end{abstract}

Gyula HORVÁTH: scientific advisor, Institute for Regional Studies, Centre for Economic and Regional Studies, Hungarian Academy of Sciences, Pécs; horvath@rkk.hu

A Pécsi Tudományegyetem Közgazdaságtudományi Karának nagy egyénisége, a magyar regionális tudomány oktatási és kutatási rendszere megteremtésének egyik jeles képviselője távozott közülünk. 2014. május 17-én tragikus hirtelenséggel elhunyt Buday-Sántha Attila professzor.

Buday-Sántha Attila 1941. november 15-én született Szekszárdon. Középiskolai tanulmányait a pécsi Nagy Lajos Gimnáziumban végezte. 1964-ben diplomázott agrármérnökként a Keszthelyi Agrártudományi Egyetemen, később agrármérnök tanári és vállalatgazdasági szakmérnöki képesítést is szerzett. 1974-ben védte meg egyetemi doktori értekezését, 1982-ben pedig a közgazdaságtudomány kandidátusa fokozatot szerezte meg. 1994-ben MTA doktora címet kapott, s ugyanebben az évben habilitált a Janus Pannonius Tudományegyetem Közgazdaságtudományi Karán. 1969-tõl gazdasági tanárként dolgozott, 1972-től a kar alkalmazásában állt, 1994-től egyetemi tanári kinevezést kapott. 1989-ben lett a kar Agrár-, Környezet- és Regionális Gazdaságtan Tanszékének vezetője.

Érdeklődési területe az agrár- és vidékpolitika, a környezetgazdálkodás és a regionális fejlesztéspolitika volt. E területekhez tartozó tárgyakat oktatott alapés mesterképzési programokon, valamint a doktori képzésben. Buday-Sántha Attilát a környezet-gazdaságtan, az agrár- és vidékfejlesztés programadó egyéniségeként, kiváló kutatójaként tartják számon. Új kutatási irányzatot alapozott meg e három tudományágazat gyakorlati (társadalmi-tervezési) alkalmazásában. Számos hazai és nemzetközi regionális és ágazati versenyképességi és fejlesztéspolitikai kutatás vezetője, koordinátora volt. Több kutatási projektet vezetett gyakorlati tervező vagy önkormányzati és kormányzati szervek megbí-

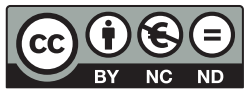


zásából. Elévülhetetlen érdemeket szerzett a regionális gazdaságtani képzés hazai elismertetése és elterjesztése területén is. Sok tudományos szervezet tagja.

Munkáját számos szakmai díjjal ismerték el, többek között Akadémiai Díjat (1986), Pro Régió Díjat (2004) kapott, elnyerte a Baranya Megyei Önkormányzat Felsőoktatási Díját (2002), a Pro Renovanda Cultura Hungariae Alapítvány Deák Ferenc kutatási díját (2008) és a FAO Élelmezési Világnap Díját (2009). Szép számmal töltött be tudományos-szakmai közéleti tisztséget. Állami kitüntetéshez nem juttatta a sors, bár igazán nem is vágyott a nem tudományos szempontok alapján történő elismerésekre. Ezeknél többre tartotta a 70. születésnapjára készített kötetet, amelyben a magyar társadalomtudomány kiválóságai, akadémikusok, professzorok, tehetséges és sikeres fiatal kutatók jelentették meg tisztelgő dolgozataikat (Bakucz, Mezei 2011).

Hosszú ideig volt titkára, majd elnöke a Pécsi Akadémiai Bizottság agrártudományi munkabizottságának és az MTA Regionális Tudományi Bizottsága felsőoktatási albizottságának. A Magyar Regionális Tudományi Társaság 2011-ben alelnökévé választotta.

Több évtizedes kutatói pályája során három kérdés foglalkoztatta, ezek kutatásában elért eredményeket az elmúlt két évtizedben szintézisbe is foglalta. Előbb az agrárpolitika, a versenyképes mezögazdaság müködése, kölcsönhatása a települési környezettel, az agrárgazdaság regionális beágyazottsága és térformáló szerepe a fejlődés különböző korszakaiban témakörben publikált nagy visszhangot kiváltott dolgozatokat. Különösen sokat foglalkozott az agrártermelés környezeti hatásaival. E kutatásainak összegzéseként az Akadémiai Kiadónál 1991-ben jelent meg A mezógazdasági melléktermékek hasznositása és a környezetvédelem című munkája. Nevéhez füződik a Balaton településkörnyezeti állapota agrártermeléshez kapcsolódó elemeinek vizsgálata. E kutatásainak összegzését A Balaton régió fejlesztése címmel a Saldo Kiadó gondozta 2007-ben.

Kutatásának második hosszú korszakában a környezet-gazdaságtan tudományos rendszerének kidolgozásával foglalkozott. E kutatási eredményeit környezetgazdálkodási nagymonográfiákban (Akadémiai Kiadó, 1993; Tankönyvkiadó, 1996; Dialóg Campus Kiadó, 2002, 2009) adta közre.

Tudományos működésének harmadik korszakában a vidék- és agrárfejlesztés kölcsönhatásainak elemzésében ért el nagy érdeklődést és elismerést kiváltó eredményeket. E kutatói periódusát az Agrárpolitika-vidékpolitika címü munkája (Dialóg Campus Kiadó, 2006) fémjelzi, amely három kiadásban jelent meg. 2011ben a Saldo Kiadónál publikált Agrár- és vidékpolitika című munkájának következtetése az, hogy a magyar mezőgazdaság a rendszerváltozást követően utat vesztett, mert képtelen a fenntarthatóság követelményeinek megfelelően a társadalmi, ökológiai és gazdasági (versenyképességi) célokat összhangba hozni egymással és azokat a fejlődés szolgálatába állítani.

Regionális fejlesztéspolitikai tevékenysége is sokrétü volt. Közremúködött országos és területi agrárgazdasági koncepciók kidolgozásában, regionális és településfejlesztési dokumentumok összeállításában. Ellenfele és éles kritikusa volt 
a provincializmus mindenfajta megnyilvánulásának. Modern, versenyképes, fenntartható vidéki gazdaság kiépítését, fejlesztését tartotta szükségesnek. Nyugdíjba vonulását követően fejeződött be az a nagyszabású kutatómunka, amely a TÁMOP finanszírozásában a Dél-dunántúli régió megújulásának belső erőforrásait tárta fel. A két tucat kutatóból álló teamet lelkesen és energikusan irányította. Vitaüléseket szervezett, volt energiája arra is, hogy igyekezzen megértetni a döntéshozókkal a stratégiaalkotás tudományos megalapozásának fontosságát. Jól tudta, hogy ez a meggyőzés kevés sikerrel járhat, hitt azonban abban, hogy a folyamatos párbeszéd eredményre vezet.

Buday-Sántha Attila publikációs jegyzékében több mint kétszáz tanulmány, 22 könyv és 10 önálló kiadvány szerepel. Munkái rangos kiadóknál és vezető szakmai folyóiratokban jelentek meg.

Aktív kutatói pályája példamutató oktatómunkával párosult. Egyéni kutatási sikerei mellett kiemelkedő a tudományszervező, iskolateremtő tevékenysége. Magyarországon az ő irányítása alatt álló tanszék indította el a környezet-gazdaságtan és alapozta meg a regionális tudomány egyetemi oktatását. Ebben a munkájában erőteljesen támaszkodott az MTA Regionális Kutatások Központjának tudományos potenciáljára. Buday-Sántha Attila hitt az egyetemi és az akadémiai szféra együttmúködésének fontosságában, e kapcsolatok alakításában kiemelkedő érdemei voltak.

Jelentős eredményeket mutatott fel a regionális tudomány többszintű egyetemi oktatásának megszervezésében. 1994-ben ő alapította Kelet- és Közép-Európa első regionális politikai és gazdaságtani doktori iskoláját, amelyben eddig több mint félszáz doktori fokozat született. Nagy figyelemmel kísérte a határon túli fiatal magyar kutatók felkészülését és pályájuk alakulását. Tíz erdélyi és vajdasági szakember szerzett tudományos fokozatot az iskolában, és sokan dolgoznak értekezésükön. Olyan tudományos iskolát teremtett, amelyben az interdiszciplináris gondolkodás, a folyamatos megmérettetés, a tudományos morál és igényesség, mások eredményeinek tisztelete volt a meghatározó. Büszkék lehetünk arra, hogy a magyar egyetemek regionális tudományi képzési programjai a pécsi iskola alapjaira épültek.

Szigorú, következetes, mindig segítőkész, kemény munkatempót diktáló, nem egyszer a porosz oktatási tradíciókra is támaszkodó tanár volt. Hallgatói kezdetben összerezzentek, ha találkoztak a mindig elegáns, egyenes tartású professzorral, féltek tőle. A hosszabb közös munkában szerzett tapasztalatok azonban gyökeresen megváltoztatták a róla kialakított képet. Harmad-negyedéven a hallgatók már tudták, Buday-Sántha professzorhoz bátran lehet fordulni a legkényesebb kérdésekben is. Dolgozószobájának ajtaja hallgatói előtt mindig nyitva állt, számíthattak rá, hogy idejével nem fukarkodik.

A tudomány határtalanságához igazodó együttműködési készség, a magyar tudományosság iránti hűség és gyarapodása iránti elkötelezettség jellemezte. Mintaadó erkölcsisége, szakmai-etikai magatartása, családszeretete különös szellemi magaslatra emelte őt. Sokan példaképként tekintettek rá. Igazi önzetlen, kö- 
zösségi ember volt. Kapcsolatépítő gyakorlatának jellegzetessége mások segítésében jutott kifejezésre. A méltányosság és az igazságosság szellemében dolgozott. Egyenes természete nem tűrte sem a hízelgést, sem az őszinteség hiányát.

Szenvedélyesen vitatkozott, nem viselt el hatalmi arroganciát és - azokban az években, amikor a közösség érdekei képviseletével bízta meg - igazságérzete védelmet jelentett a jogtalanul támadottaknak. Az innovatív elképzelések megvalósításáért is sokat kellett küzdenie, szakmai tekintélye azonban inspiráló erő volt a kétkedők vagy ellenkezők meggyőzésében.

Nagy egyéniség volt, a szellem úriembere, kiválóságot teremtett, értette a lényeg nyelvét, és értékké tette, amihez hozzáfogott. Távlata van azoknak az értékeknek, amelyek hozzá kötődnek. Nem szabad ezt a szellemi teljesítményt veszni hagyni, továbbépíteni a szűkebb egyetemi közösség, a tágabb régió és az ország érdekében - mindannyiunk kötelessége. Ő beletörődéssel vette tudomásul azt a végig nem gondolt oktatáspolitikai döntést, hogy nincs már szükség a bölcs, idős generáció tudás- és értékgyarapító munkájára. Rezignáltan fogalmazott tavaly a székelyföldi regionális kutatók konferenciára invitáló levelére: „Nagyon örülök, hogy Székelyföldön kialakult egy eredményeket is felmutatni képes tudományos közösség. (...) Ez volt a célunk, amikor támogattuk a Ti tanulmányaitokat. Nyugdíjazásom következtében már nem vagyok olyan helyzetben, hogy a jövővel kapcsolatos terveket szőjek. Ezért nem jelentkeztem a konferenciára. (...) Sok szeretettel gondolok Rátok, de csak ezzel tudlak támogatni Benneteket." Tanítványai szomorúan olvasták ezeket a sorokat.

Buday-Sántha Attilának az elmúlt pár évben elért sikerei is figyelmeztessenek bennünket a sok történelmi korszakban megtapasztalt igazságra: emelkedő társadalomban építenek a nagy öregek tanácsaira, csak süllyedő közösség hagyja figyelmen kívül azokat. Az áhított versenyképesség - országé, egyetemé - fontos morális előfeltétele ez.

Egyéniségét több ezer közgazdász, agrár-, környezet- és regionális kutató, terület- és településfejlesztési szakember zárta a szívébe. Tanításaira, könyveire, példamutató magatartására, igazságszeretetére, kérlelhetetlen egyenességére hosszú ideig emlékezni fognak. Tudományos ethosza követendő példa a fiatal kutató generáció számára.

\section{Irodalom}

Bakucz M., Mezei C. (szerk.) (2011): Agrárátalakulás, környezeti változások és regionális fejlődés: Tanulmányok Buday-Sántha Attila 70. születésnapjára. Pécsi Tudományegyetem Közgazdaságtudományi Kar, Pécs 


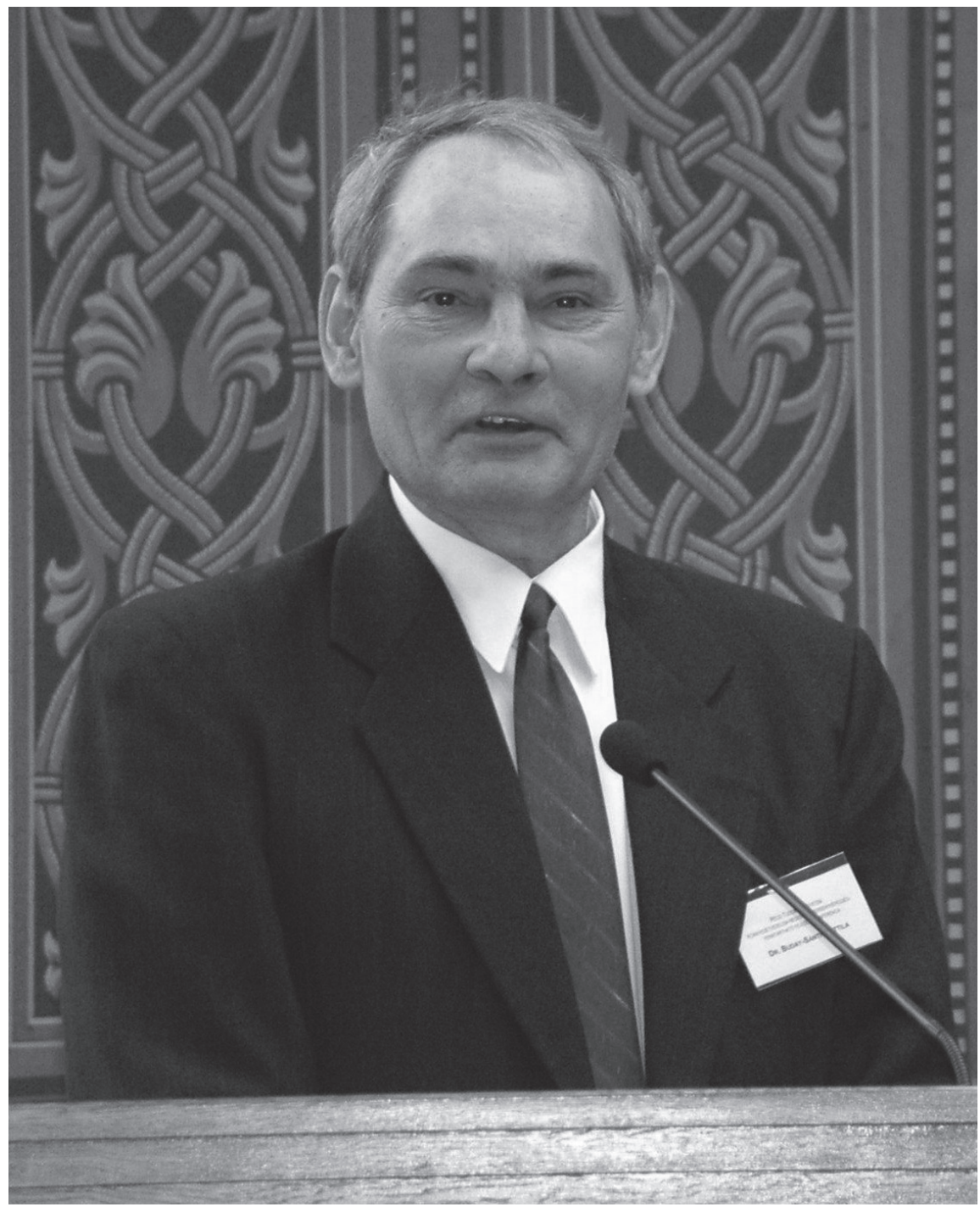




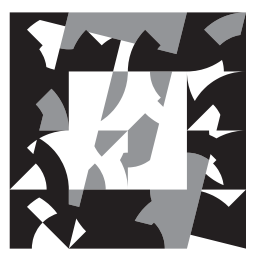

TÉR ÉS TÁRSADALOM | SPACE AND SOCIETY 